\title{
Discourses, Identities and Investment in English as a Second Language Learning: Voices from Two U.S. Community College Students
}

\author{
Yueh-ching Chang \\ Institute of Teaching English to Speakers of Other Languages, National Chiao Tung University, Taiwan \\ E-mail: yuehchingchang@nctu.edu.tw
}

Received: 13-09- 2016

doi:10.7575/aiac.ijels.v.4n.4p.38
Accepted: 20-10-2016

URL: http://dx.doi.org/10.7575/aiac.ijels.v.4n.4p.38
Published: 31-10-2016

\begin{abstract}
Adopting a qualitative case study methodology, the present study illuminates how two multilingual students enrolled in a U.S. community college ESL class negotiated the sociocultural norms valued in their multiple communities to make investment in learning English in college. Drawing on Gee's theory of Discourse and identity (1996) and Norton's theory of investment (2000), the study found that each student's investment in learning the language practices of the classroom was shaped by the diverse Discourses in which they participated across time and space. Despite confronting structural constraints, the focal students were able to mobilize their multiple Discourses to negotiate the existing sociocultural norms and invest in identities that have the potential to transform their lives. These findings suggest that multilingual students' learning at the college is shaped by their socio-cultural milieu and future aspirations. Thus, language educators should recognize their multiple identities as well as their agency, and broaden the curriculum goals to accommodate their diverse linguistic and educational needs.
\end{abstract}

Keywords: Discourses, identities, investment, community college, ESL, multilingual students

\section{Introduction}

The American community college has been known as the "people's college," where anyone can be accepted and educated for academic transfer to four-year universities, vocational and technical training, as well as civic and continuing education (Cohen \& Brawer, 2008). Such an open-access policy attracts many culturally and linguistically diverse students who perceive the community college as the institution that provides access and opportunity to postsecondary education and/or career advancement for social and economic mobility. To serve a large number of multilingual students, many U.S. community colleges provide English as Second Language (ESL) instruction in order to assist them to gain the English language skills necessary to participate in society and/or succeed in college-level courses (Blumenthal, 2002; Bunch, 2008; Kuo, 1999).

Although research on community college ESL has shed some light on students' ESL learning within the context of community colleges, much research tends to focus on the role that community colleges play in teaching the English language skills that students need for functional literacy (Chisman \& Crandall, 2007; Condelli, 2004; Cracdall \& Sheppard, 2004) or academic demand at college (Curry, 2004, Miele, 2003; Roberge, Siegal \& Harklau, 2009). This perspective, however, treats students' learning at colleges as a monolithic, one-way assimilation into existing social and academic norms, rather than a more complex process of negotiating the diverse sociocultural norms that their multiple communities assert on their educational experiences (Becker, 2011; Kanno \& Varghese, 2010). As Levin (2007) noted in his research on nontraditional students in American community colleges (e.g., immigrants and working adults), we must understand these students' college experience with the assumption that "college' for students cannot be viewed or understood as the principal or primary community ... College is situated within the life experiences of students and the environments they inhabit, as well as the community with which they interact on a daily basis" (p.65). Indeed, in addition to acquiring sufficient English language proficiency to participate in college classrooms, many community college students are simultaneously members of multiple communities that intensively intersect with their learning experience at college. Their sociocultural membership outside the college classroom (including ethnic and cultural values, family roles, and future social and career aspirations) may have greater impact on their learning of ESL in the college classroom.

To illuminate how macro sociocultural contexts assert influence on students' ESL learning in community colleges, the study adopts a qualitative case study methodology (Hood, 2009; Merriam, 1998) and draws on Gee's theory of Discourse and identity (1996) and Norton's theory of investment (Norton, 2000; Norton \& Toohey, 2011) as theoretical frames to examine the learning experience of two multilingual students enrolled in a U.S. community college ESL class which focuses on developing academic writing competence. In the rest of the paper, literature on community college ESL in the U.S. is examined to provide an in-depth background and connect this study with current research. Then, a detailed 
explanation of the theoretical frames and the methodological procedures allows us to interpret the data from a perspective which generates a more contextual understanding of the focal students' ESL learning experience. The findings portray how each of the focal students, drawing from their agency and personal aspirations, negotiated the Discourses (i.e., the sociocultural norms) valued in the multiple communities they participate in to make investment in learning English writing in the community college ESL classroom. Finally, in light of the two focal students' ESL learning experiences, I discuss the implications they have on understanding multilingual students' ESL learning process as well as ESL curriculum planning.

\section{Community College ESL in the U.S.}

In response to the growing body of non-English speaking students in the U.S. higher education, most community colleges provide ESL instruction in order to assist culturally and linguistically diverse students gain the English language skills necessary to participate in society and/or succeed in college-level courses ${ }^{i}$ (Blumenthal, 2002; Bunch, 2008; Kuo, 1999). Although students enrolling in community college ESL courses are extremely diverse in their ethnic, cultural, and linguistic backgrounds, they tend to belong to one of the four broadly defined populations: (a) generation 1.5 students who have completed most of their schooling in the United States, yet are still struggling to reach English language competency in college-level academic work, (b) recent immigrants who have recently arrived in the U.S., (c) international students who are in the U.S. on student visa, and (d) long-term adult immigrants who are pursuing a career objective for which they need advanced English language skills (Blumenthal, 2002; Bunch, 2008).

To understand the ESL learning experience of such a diverse student population, research in college-level second language (L2) writing has contributed to illuminating their process of acquiring academic language skills and socializing into certain academic genres (see Cheng, 2008; Hyland, 2007; Leki, 2007; Roberge, Siegal, \& Harklau, 2009; Zamel, 1995). Nevertheless, much research on multilingual students' L2 writing practices tends to draw an arbitrary line between the college writing classroom and the macro context the students are situated in, assuming students' process of learning to write as socializing into existing social and academic norms (Kanno \& Varghese, 2010; Matsuda, 2006). Not until lately have several L2 writing scholars shifted their attention to the broader social norms and institutional ideologies that may shape L2 writing practices (see Liu \& Tannacito, 2013; Matsuda, 2006; Matsuda, Ortmeier-Hopper \& You, 2006). For instance, Matsuda (2006) challenged the English monolingual ideology circulated in U.S. higher education for it dismisses the knowledge brought into the writing classroom by multilingual students. Liu and Tannacito (2013) illuminated how certain forms of racial and language ideologies (e.g., white prestige ideology) affected two multilingual students' learning of academic English writing in a college classroom.

Meanwhile, educational researchers have also contributed to illuminating the impact of the macro sociocultural context on students' ESL learning and educational experience in community colleges (see Becker, 2011; Harklau, 2000; Kanno \& Varghese, 2010; Razfar \& Simon, 2011). For example, in a case study of three immigrant students' transitions from high school to community college, Harklau (2000) found that community college ESL programs tend to assume that all multilingual students are cultural novices in need of socialization into U.S. college norms. Such an institutional ideology was dissonant with the experiences of some students and had a debilitating effect on their ESL learning in community college. Kanno and Varghese (2010) examined the challenges that first-generation immigrant students, including community college students, face in accessing four-year colleges. Their findings suggest that what inhibits these students' participation in 4-year college education is not simply their limited English proficiency, but also the structural and economic constraints unique to this population. Drawing on interview data from 17 adult students moving from noncredit to credit ESL programs in community colleges, Becker (2011) identified the impeding factors in the students' personal lives that interfered with their ESL learning experience in community colleges.

Even though findings from the aforementioned studies have shown that the macro social, cultural, and political context may affect the multilingual students' ESL learning in college, more studies are needed to illuminate how multilingual students negotiate diverse, and sometimes conflicting, sociocultural norms that the broader contexts assert on their learning experiences in the college ESL classroom. As Becker (2011) notes, in understanding students' learning of ESL at community colleges, the "biggest challenge was their shifting sense of who they were, where they fit in their new cultural milieu, and with which social groups to associate - and from which groups to distance themselves" (p.21). Razfar and Simon (2011) also called for future research that portrays students' educational experience in community college ESL classrooms, taking into consideration how the students' life worlds outside the college classroom affect their college experiences. Situated in the macro sociocultural contexts of two multilingual students enrolling in a U.S. community college, the present study aims to illuminate how the students negotiated the sociocultural norms of their community college ESL classroom while participating in their communities outside the college.

\section{Theoretical Framework: Discourse, Identity and Investment}

Gee's (1996) notion of Discourse and identity and Norton's notion of investment (Norton, 2000; Norton \& Toohey, 2011) form the theoretical lens of the study. Grounded on a poststructuralist perspective on language, identity, and L2 learning (Pavlenko, 2002), these theoretical frames afford us to contextually examine students' schooling experience as a complex and dynamic process, including power relations among people, institutions, social identities, and individual agency. 
Extending conventional notions of discourse as language in use, Gee (1996) conceptualizes one's language use as mediating different socially and historically situated identities. His notion of big D Discourse embodies language and other dispositions that signal one's sociocultural membership, defined as:

a socially accepted association among ways of using language, other symbolic expressions, and 'artifacts', of thinking, feeling, believing, valuing, and acting that can be used to identify oneself as a member of a socially meaningful group or 'social network', or to signal (that one is playing) a socially meaningful 'role' (1996, p. 131)

In other words, a Discourse is a combination of material and expressive resources which acts as an "identity kit" (2001, p.526). One's identity is recognized by a particular social group based on its "interpretive system” (2000-2001, p.107), which is to say, institutional norms, taken-for-granted cultural beliefs, common sense gender behaviors, and so forth. A Discourse, thus, is the valued language forms and the taken-for-granted norms, values, beliefs, and behaviors of a particular social group.

Gee (1996) further contends that Discourses are always multiple, and the different Discourses that one possesses interact in complicated ways. In addition to the primary Discourse that one acquires early in home-based socialization, there are arrays of secondary Discourses that one acquires within social institutions, such as community organizations, schools, workplaces, or governments. While some degree of conflict will almost always be present between two or more of their Discourses, for some people, there are more overt conflicts than there are for others because some of the Discourses valued in their home-based communities may be in conflict with the Discourses upheld by mainstream social institutions, such as schools. Norton's theory of investment further allows us to examine how L2 learners negotiate their multiple, and sometimes conflicting Discourses, and attribute meaning to the investment in learning.

\subsection{Investment and Second Language Learning}

Norton (2000) suggests that when learning an L2, learners are human agents who "are constantly organizing and reorganizing a sense of who they are and how they relate to the social world" (p.18). At times, they may have unique means of self-representation in the new communities that prompt them to cross boundaries and assimilate to the new communities or to become members of multiple communities (see Gordon, 2012; Morita, 2009). Yet in other situations, they may see their new identities proffered by the new language as undesirable, and resist assimilating to the norms of the new communities (see Norton, 2000; Vann, Richardson, \& Escudero, 2006) or create a "third space" in which they form new identities (see Higgins, 2011; Jackson, 2011). In this view, agency is always co-constructed by individual free will and the macro sociocultural context (Darvin \& Norton, 2015; Norton \& Toohey, 2011). That is, although what learners desire can be shaped by structural constraints of the macro context, "it is through desire that learners are compelled to act and exercise their agency" (Darvin \& Norton, 2015, p. 46). Thus, learning, in general, and L2 learning, in particular, always involves compliance with as well as resistance to the sociocultural norms of the macro contexts, depending on how learners perceive the economic value (i.e., material goods, such as property and income) and symbolic value (i.e., non-material resources that bring social and cultural power, such as social networks and the educational credential) of the language.

Furthermore, learners' investments in different language skills are selective, and different skills have different values in relation to the multiple Discourses and identities they desire to affiliate with (Norton, 2014). Their selective investment in learning the L2 is not only shaped by the immediately accessible communities that people directly interact with, such as schools, neighborhoods, and the work place, but also their imagined community, that is "communities include future relationships that exist only in the learner's imagination as well as affiliations--such as nationhood or even transnational communities--that extend beyond local sets of relationships" (Kanno \& Norton, 2003, p. 242; also see Norton, 2014). Hence, not only the affiliation with the immediately accessible communities, but also learners' imagined affiliations could differentiate their choices of investment in learning different language skills.

In sum, the theoretical frames adopted by the study inform us that the focal students reside among multiple Discourses to attribute meaning to their educational goals and their investment in learning ESL in college. They may comply with some of the Discourses and might contest others, depending on the sense of self they desire to project in relation to the perceived material and symbolic values of the language. Hence, the attempt to understand their investment in ESL learning inside and outside the college needs to take into account the multiple Discourses and identities of their immediately accessible communities as well as their imagined communities.

\section{Methodology}

This is part of a larger study (Chang, 2010) that employed the qualitative case study methodology (Hood, 2009; Merriam, 1998) to investigate six community college students' identity socialization as they learned ESL at a U.S. public community college that prioritizes the mission of transferring students to four-year universities over the other college missions, such as vocational-technical education and community services. While all the students have stories of complexities in their lives, to illuminate their identity negotiation in nuanced details, the current study focuses on two of the students --Charlene and Vincent ${ }^{\mathrm{ii}}$. These two students were selected because their status as new arrival and working students would vividly manifest how they negotiated their multiple Discourses. In addition, their contrasting 
characteristics in terms of gender roles, academic aspirations, and educational goals allowed us to examine their differential investments in learning ESL at the college.

Data were collected over one semester from multiple sources, including: (a) five semi-structured interviews with each focal student, (b) two interviews with the instructor of the ESL class, (c) field notes taken during 16 weeks of participant observation in the ESL class, and (d) artifacts, such as writing samples, course materials, and evaluation sheets. The interview protocol (see Appendix A) covered questions about the students' previous educational and English language learning experiences, their social life in the U.S., their academic/career goals, and their perceptions of attending this ESL class. To gain an in-depth account of the informants' perspectives by removing the language barriers, the focal students were given choices on whatever languages they feel comfortable with in the interview since the informants and the researcher share similar language repertoires. Interviews with the course instructor (see Appendix B) focused on the intended course goals, the instructor's comments on the focal students' learning attitudes, and her perceptions of the focal students' ESL development. The interviews with the focal students and the instructor of the ESL class were recorded and transcribed verbatim.

Data were coded and analyzed following a "constant comparative method" (Glaser \& Strauss, 1967); that is, salient themes and categories were generated after reviewing the collected data several times and comparing/contrasting the data of different sources iteratively. I initially read the transcript of the student interviews, using open codes with $A T L A S t i$ to identify the key categories that were associated with the students' higher education and ESL learning experience. Then, when reviewing these key categories, I sub-categorized them by the various communities that these key categories were associated with, and the sociocultural values that are highlighted in these communities. Triangulation of different data sources contributed to validating the analysis by bringing in multiple viewpoints. Through comparing and contrasting the data iteratively, the study was able to map out the Discourses the focal students participated in, and show how these Discourses, even if conflicting in nature, worked in tandem to shape the students' perceptions of the college goals and their investment in learning ESL.

\section{Results}

Within the ESL classroom where Charlene and Vincent were situated, academic Discourse was highlighted as the students were socialized into a specific type of academic writing genre which consists of a fixed set of stylistic and syntactic structures - in particular, a written format of topic sentences, supporting details, and concluding sentences, as well as formal as opposed to colloquial vocabulary. In the interview, the course instructor acknowledged that "this is an academic writing course that helps the students develop a topic sentence with supporting points." The focus of developing students' academic writing competency was substantiated in the curriculum as the students' essay assignments accounted for $85 \%$ of the final course grade. As indicated in the instructor's essay grading rubric, these writing assignments required the students to write multiple-paragraph essays which develop a thesis with supporting details, using appropriate transitional devices, compound and complex sentence structures, and college-level vocabulary. In addition to the essay assignments, a class-bound online forum was defined by the instructor as "more opportunities to practice academic writing at home," rather than casual, friendly exchange as most online forums would afford. In face-to-face classroom interaction, I also observed that the students were not only, from time to time, asked to explicitly rehearse this distinctive type of academic English writing genre, but also frequently guided to follow the academic practice of finding textual evidence for claims in their oral responses to the instructor's questions. Essentially, mastering this monolithic writing genre indexes an identity as a capable student within this ESL classroom (also see Chang \& Sperling, 2014). The following sections illuminate how Charlene and Vincent, situated in such an academic-writing-focused ESL classroom context, mobilized their multiple Discourses to make investment in their ESL learning.

\subsection{Charlene}

Charlene was a twenty-six-year old female student from Malaysia. The daughter of an affluent Chinese immigrant family in Malaysia, Charlene had attended a school which offered Chinese-mediated instruction in Malaysia, and was capable of speaking fluent Mandarin Chinese and Cantonese, in addition to Malay, the official language of Malaysia. She had also learned English at school since the age of nine, but did not rate herself as a competent English user. After high school, she went to an art college in Kuala Lumpur for one year. In 2004, hoping to continue her undergraduate education in the U.S., Charlene came to stay with her sister, who was a permanent resident in California. Nevertheless, with her academic interests vacillating, Charlene decided to look for a job, trying to figure out her academic pathway from her work experience. In 2006, she married her husband, an Asian American working as a government officer, and became a permanent resident in the U.S. With financial security, legal immigration status, and a stable social network in the U.S., Charlene decided to start her college life in the fall of 2007, while keeping her job in a printing company.

\subsubsection{Discourses and College Education}

Despite attending college with working status, Charlene was a highly motivated student who, at the time we met, had maintained an outstanding grade record in all the courses she had taken at the college. When asked about her educational goals, Charlene said that she would try to get an associate degree from the community college and then transfer to a fouryear university for a bachelor's degree. Nevertheless, she appeared to be reserved and uncertain when talking about this goal. In the interview, she said, 
I really would like to get a bachelor's degree, but I feel ashamed if I tell people about it and can't reach the goal eventually. Because I am married, and because of my age, I feel I'm at a slower track than everybody else. So, I just tell people that an AA degree is good enough for me. Because my mother and sisters all tell me it's better for a woman to get married before 28 , considering things like giving birth. They told me it's better for women to have babies before 30. But when I saw their life centered around their children after they gave birth, I told myself I don't want to be like that. I want to get the degree before I give birth.

The home-based gender expectations of women getting married at a "desirable" age and the responsibility of childcare seemed to sharply interfere with Charlene's sense of college goals.

Although the goal of getting a bachelor's degree could potentially threaten the gender expectations of her home community, Charlene's persistence in pursuing the goal of college transfer can be understood from the value she attached to the higher education she received in the U.S. Her perception of higher education indexes an instrumental Discourse which associates a bachelor's degree with advancing her future career and increasing her income. Nevertheless, more important than the economic returns, Charlene perceived the symbolic value of cultural approbation that a bachelor's degree would bring her. She said in the interview,

I feel embarrassed about not being able to finish my undergraduate education. ... Maybe I never have a bachelor's degree, so I really want it badly. I think a bachelor's degree is very common in the [U.S.] society. Many people have degrees in masters or Ph.D. My husband and his sisters all got masters. ... When I started to go to college, I found going to college acculturates people and makes people more knowledgeable. That makes me feel like I'm different from people who have never attended college.

Charlene was willing to transgress the gender expectation of her home community to pursue a bachelor's degree for she perceived not only the economic value but also the symbolic value of sociocultural approbation among family members and friends.

\subsubsection{Discourses and Investment in ESL Learning}

Charlene's investment in learning ESL at the college is shaped by three Discourses. Firstly, learning English indexes an economic value which will be cashed out in her future career. When asked about why she regards learning English as important, Charlene said without hesitation,

Because I'm in America, because I want to work for big companies, most of the big companies are American companies, so I have to speak English. ... I always think that now I have a stable job, but it cannot guarantee me, like ten years later, they still will pay me well, so I have to prepare for that. I think big companies will give me more benefits and a more stable job.

It appears that Charlene linked learning English with the instrumental rewards gained from her imagined community of the future workplace.

In addition to the instrumental Discourse, Charlene's investment in learning English is also shaped by the Discourse of English speaker privilege which associates the English language with admiration for the West and whiteness (see Liu \& Tannacito, 2013). Speaking of the importance of learning English, Charlene said,

I have liked western culture since I was a kid. I also like western customs, maybe because I don't like Chinese customs as much, I don't know. I always think foreigners are better and they are prettier, they seem to be perfect. Anyway, I just like foreigners and I always want to marry foreigners. ... For example, among all the boyfriends I have, only one of them is not a foreigner. He is a Malaysian, but he is a mix of white and Malay. His eyes are bling bling, just like foreigners. (Charlene giggled.) I dated him because he speaks English well.

Charlene conflated English with the "western culture" and "western customs" and "people who speak English well" with "foreigners," specifically the "white," who are "prettier" and "perfect." Speaking English and socializing with people who speak English well index an appropriation of a culturally-privileged imagined identity.

Perhaps the most important Discourse that shaped Charlene's investment in learning English at the college was the academic Discourse that associates learning the monolithic academic writing genre promoted in the ESL classroom with the identity of capable students in the immediate classroom community. Speaking of her ESL learning experience in the college, Charlene was constantly concerned about her course grades which would affect her opportunities of transferring to a four-year university.

I thought [the ESL class] wouldn't be as difficult, but, it turns out the pressure is a lot. There are many assignments, too many assignments for me. But I told myself I cannot drop this course because if I drop, I would get a W in my transcript. ... You know I got A's in all of my other courses, I still keep a 4.0 GPA. I am worried if I don't get a good grade in the ESL class, it would lower my GPA.

To keep a good academic record, Charlene had to comply with the academic Discourse and invest a great deal of effort in the monolithic academic writing genre promoted in the ESL classroom. When commenting on her experience with one of the course writing assignments, Charlene said in the interview: 
Although sometimes I feel stressed about why the teacher gives us so many writing assignments, although I complained, I know this is good for us to improve our English writing. ... Like I got my last assignment, the paragraph assignment, I got a C. I was very sad and frustrated. I feel, "Oh, my god, I mess it up!" but then I said, "Although it's a challenge, I need to overcome it because we're going to do English writing in other classes and other classes won't be easy."

To master this formulaic writing genre, Charlene not only frequently asked for help from the ESL tutors at the college, but also hired a private English tutor to help her edit the course essays. In the ESL class, I observed that Charlene attended course meetings regularly with good preparation and turned in the course assignments on time. In the interview that took place at the end of the academic term, the instructor commented that although Charlene did not start out as a strong academic writer, she turned out to be "the best academic student in class," who "stood out among the other students in terms of her writing ability." For Charlene, an investment in learning the monolithic academic writing genre valued in the ESL classroom was an investment in the identity of a capable student in the immediate classroom community, which is closely related to her imagined identity as a bachelor degree holder.

\subsection{Vincent}

Vincent was a 30-year-old single male student who came from Shanghai, China in 2006. In addition to his native language, Chinese Mandarin and Shanghainese (i.e., a local Chinese dialect), Vincent also learned English as a school subject in China since he was 12, but had never used English for meaningful communication before arriving in the U.S. He had graduated from a vocational high school in China, majoring in art and design. After graduating from vocational school, he had had extensive work experience as a graphic designer and film editor for companies in China. In order to improve his professional skills, Vincent decided to study in the U.S. on an F1 student visa. Since arriving in the U.S., he had been living alone in the Chinese ethnic community. Besides attending college, Vincent also worked without legal permission as a freelance graphic designer and children's art teacher for companies in the Chinese ethnic community in order to cover his living expenses in the U.S. and the costly international student tuition.

\subsubsection{Discourses and College Education}

Vincent gained satisfaction and confidence at the college from his achievement in vocational skills. In the two years prior to the study, he had obtained a certificate of graphic design from the college, and earned a scholarship to take art courses at a renowned art college. Rather than cultivating his academic skills and bidding for excellent academic records in his transcript as Charlene did, Vincent's goal was to pass as soon as possible the General Education Requirements, such as the ESL course so that he could earn the college degree. With this degree, he planned to market himself in the job arena, if possible, in the U.S., but, ultimately, in his economically booming homeland - China. When asked about his educational goal at the college and future plans, Vincent said:

I have completed a certificate of graphic design. [To obtain the associate degree] I just have to finish the required courses for General Education. I have to finish them soon because the tuition is expensive and those courses seem to, they don't seem to enhance my occupational skills much. ... After I get the degree, I might try to get a job in the U.S. I regard it as an internship and I can accumulate some work experiences in the U.S. Then, I will return to get a job in my homeland. In this way, it will be easier for me. ... I can earn more and I might be able to participate in joint projects with American film production teams in China since I have some working experience in the U.S. and know their culture, and I can speak some English.

Like Charlene, Vincent's perception of higher education seemed to reflect an instrumental Discourse, foregrounding the instrumental value of getting a better job and gaining financial stability through professional skills training provided by educational programs. Nevertheless, prioritizing his vocational-oriented goal, Vincent perceived the academic courses required in General Education, such as ESL, math, and biology, as simply a requirement that would not really advance his vocational skills.

Furthermore, Vincent's college goal was also shaped by the Discourse of globalization which gives symbolic value to his transcultural and translingual identity. In fact, in China, there is a growing group of social elite referred to as "sea turtles," which is a pun on "haigui," meaning "returned from overseas" (Wang, 2012). Drawn by the growing political influence and economic boom of China since it launched its open door policy in 1978, unprecedented waves of overseas students who have studied and worked in the U.S. and European countries are returning to their homeland. Their transcultural and translinguistic identity usually designates them as "bridgemen" who play a pivotal role in globalizing and bridging China with the world. Thus, for Vincent, a better future might lie in his homeland, the globalizing China, where his imagined identity as a transnational "bridgeman" who has the linguistic and cultural dispositions to participate in transnational film production could not only earn him a decent monetary reward, but could also assist him in climbing the social ladder.

\subsubsection{Discourses and Investment in ESL Learning}

Similar to Charlene, Vincent also perceived learning English as essential to the immediate communities he participated in in the U.S. and the imagined future work communities: 
Because this is America, you have to learn English. You need it in daily life. And if I get a job offer in the U.S., I also need English.... In addition, it may help me when I return to work in China in the future. After all, English is still the international language.

Vincent's investment in learning English appeared to be grounded in an instrumental Discourse that stresses the functional literacy of English in his daily life as well as his imagined future workplace. In addition, his investment in learning English was also shaped by the Discourse of globalization which assumes that English is the "international language," a lingua franca in the globalizing world (Crystal, 2012; Graddol, 1998). Vincent appeared to associate his ability of speaking English with his imagined bridgeman identity in the globalizing China. Portraying his future job opportunities in China, he said in the interview:

Even though Chinese is becoming an important language because many people want to do business with China, English is still the international language. If I can finish my degree and get an internship in a U.S. company, then I can speak both languages well. This is going to give me more edge in the job market.

Nevertheless, unlike Charlene, Vincent was ambivalent about acquiring the academic written English upheld in the ESL classroom:

There are two reasons why I took this [ESL] class. First of all, I need to pass this class so that I can finish my General Education. Secondly, I would like to improve my English language. I might need it when I start to work in the future. ... But I think this course is too much and too difficult for me, especially writing essays. I hate writing essays. It's too much for me. ... I feel it doesn't matter if I study for it. It doesn't make a difference anyway. ... Writing English essays is just a course requirement. I don't think I will need to write essays in the future.

From Vincent's perspective, learning English was not associated with transferring to a four year university, but with his functional literacy and future work skills. Therefore, he was reluctant to comply with the academic Discourse promoted in the ESL classroom as he said in the interview, "I just wanted to engage enough to pass the class" "I feel it doesn't matter if I study for it. It doesn't make a difference anyway." In my observation of the ESL classroom, he was late or absent from the class many times and submitted homework late for obscure reasons. He was lukewarm about advancing his academic writing skills and even got caught asking one of his friends to "help" him too much on his writing assignments. In the end, Vincent got a $\mathrm{C}$ for his final course grade as the instructor commented in the interview "he is not as academically capable as the others. I think he is going to be in trouble in the next level [of the ESL class]."

Although ambivalent about investing in learning the formulaic academic writing genre, Vincent appeared to invest in oral English with enthusiasm in the ESL class. Commenting on Vincent's oral participation in class, the ESL instructor regarded Vincent as "an interesting student who got some good ideas. A student who is really engaged in the topic" and "Somebody who wants to engage more, but struggles with the vocabulary and sentence structures." In my observation of the classroom, I noticed that Vincent, in fact, was one of the most talkative students in the ESL class. Commenting on his classroom participation, Vincent said,

I think I'm fine with class participation. I don't feel embarrassed about asking questions. Anyway, I can practice my English speaking even if I made mistakes. ... Also American teachers like students ask questions. So, I have no problem speaking up in the class.

Rather than investing in the formulaic academic written English, Vincent perceived being vocal in the class as an opportunity to develop his oral skills in English and a means to present himself as an enthusiastic learner. For Vincent, an investment in spoken English was an investment in his imagined identity of a bilingual bridgeman as well as the identity of a student who can pass the class.

\section{Discussion}

Findings from the study suggest that Charlene and Vincent are members of multiple communities in addition to the community of the college classroom. They simultaneously negotiated with the academic Discourse promoted in the college ESL classroom as well as the Discourses of their other communities outside college. Finding a balance between the school-based and their home- or community-based Discourses was a constant struggle for them. Charlene had to resist the gender Discourse valued in her home community and keenly appropriate the academic Discourse in order to acquire the desired economic and symbolic values indexed in her college education. Shaped by the Discourse of globalization, Vincent had to negotiate his vocationally oriented goals and an imagined bridgeman identity within a college that upheld academic transfer and valued the acquisition of a monolithic academic written English. These two students remind us that the diverse Discourses that each student participates in may affect their alignment with the mainstream school-based Discourse (Gee, 1996), and finding a balance among these diverse Discourses is a different battle for each student to fight (Chang, 2011).

Aligning with the current research on students' selective investment in learning the L2 (Haneda, 2005; McKay \&Wang, 1996), this study found that the focal students' investment in learning ESL at college is not only selective but, more importantly, their selective investment is shaped by both the immediate and the imagined communities in which they participate. From Charlene's perspective, the investment in learning academic written English not only assured her 
identity as a capable student in the immediate classroom community, but also her future aspiration as a bachelor's degree holder as well as her sense of cultural approbation. For Vincent, an investment in the academic written English promoted in the classroom was not worthwhile for it did not necessarily satisfy his workplace or daily life needs in the immediately accessible community, and neither did it have much value in his imagined community as a transnational bridgeman. He was willing to invest in oral language skills for such an investment won him the identity of an enthusiastic learner in the immediate classroom community and furnished his imagined identity of a bridgeman who speaks both Chinese and English well. Their stories suggest that learners' investment in learning a language is not only selective, but also shaped by their membership of the various communities across time and space, including their imagined future identities (Norton, 2014). Particularly, Vincent's case vividly illustrates that as the transnational flow of people and ideas becomes a common trend in the globalized world, learners' connection with their imagined communities may exert an extremely powerful influence on their investment in the language practices of the immediate classroom community (Darvin \& Norton, 2015).

Finally, while previous studies on multilingual students' educational experience in community colleges have tended to regard structural constraints as impeding factors that create barriers to students' educational opportunities (e.g., Becker, 2011; Harklau, 2000; Razfar \& Simon, 2011), Norton and her colleague acknowledge human agency in negotiating structural constraints: "[Learners'] habitus, shaped by prevailing ideologies, predisposes them to think and act in certain ways, but it is through desire and imagination that they are able to invest in practices that can transform their lives" (Darvin \& Norton, 2015, p. 46). This study further manifests that despite confronting structural constraints, Charlene and Vincent were able to assert their individual agency, mobilizing within the multiple Discourses to negotiate and reshape the existing structural constraints. For example, while the home-based gender Discourse appeared to interfere with her college goal, Charlene was willing to transgress the gender Discourse valued in her home community, working extra hard to acquire the academic Discourse. In a similar vein, shaped by his imagined identities, Vincent was hesitant to comply with the academic Discourse promoted in the ESL classroom, and deemphasized learning the formulaic academic writing genre in his ESL learning process. He was able to find a "third place" (Kramsch, 1993) which allows him to bypass the academic Discourse, present himself as a vocal student who can pass the ESL requirement, and develop oral fluency to furnish his imagined bridgeman identity. These two different L2 learning experiences suggest that although restricted by the constraints of the macro context, multilingual students do not necessarily subjugate themselves to the existing institutional norms or sociocultural values of larger social structures. As human agents, their desire and imagination prompt them to invest in practices that have the potential to transform their lives.

\section{Conclusion and Implications}

Adopting a qualitative case study methodology, this study portrays how two multilingual students enrolled in a U.S. community college ESL classroom negotiated with their multiple Discourses to make meaning of their English learning. Although focusing on only two students in one institutional context, the study has implications for the education of students learning ESL at American community colleges as well as other higher educational institutions that host multilingual students. The theoretical frames adopted by the study provide ESL educators with an alternative perspective to understand multilingual students' English learning, perceiving them as complex human agents mobilizing among multiple Discourses, rather than assuming that they attend college with the sole goal of assimilating into the mainstream school Discourse. Particularly, in a globalized world, the notion of "language learner" has to be understood as a complex individual possessing a wide range of dynamic social and contextual identities (Higgins, 2011). As shown in this study, both Charlene and Vincent were closely affiliated with their immediate as well as imagined communities, and referred to the values and practices of these communities to make investment in their language learning activities in college. Thus, in pedagogical practices, ESL educators need to spend time getting to know the investment students make in their learning of English and adopt a more student-centered approach, encouraging students to articulate their voices and feelings when learning English and empowering them with the skills they need to take control of their life (Flowerdew \& Miller, 2008; Norton, 2000). Lack of awareness of students' identities associated with their distinct, but interrelated, communities across time and space could compromise a student's investment in the language practices of the classroom (Norton, 2014).

Furthermore, this study also has implications for the community college ESL curriculum. Along with Razfar and Simon (2011), the study shows that the educational goals of some multilingual students in community colleges are career or basic skills development, rather than academic transfer. For example, while Charlene has an academic goal of transferring to a four-year university for a bachelor's degree, Vincent clearly has a goal of getting career advancement through the college credential and developing a bridgeman persona who is capable of crossing linguistic and cultural boarders. Hence, the common assumption that most multilingual students come to U.S. colleges in pursuit of academic success/literacy may be a misconception. Since American community colleges undertake multiple social functions and enroll students with diverse educational goals (Cohen \& Brawer, 2008), the study suggests that community college ESL programs should have broader and more diverse curriculum goals, such as accommodating students' linguistic needs at workplace and developing literacy repertoire for their current life demands as well as future aspirations. A narrow curriculum goal that solely focuses on facilitating academic transfer and promoting a monolithic genre of academic language not only dismisses the other educational mission of community colleges, but also marginalizes the linguistic needs of students enrolling with goals other than academic transfer. 


\section{References}

Becker, L.A. (2011). Noncredit to credit transitioning matters for adult ESL learners in a California community college. New Directions for Community Colleges, 155, 15-26.

Blumenthal, A. J. (2002). English as a second language at the community college: An exploration of context and concerns. New Directions for Community College, 117, 45-53.

Bunch, G. C. (2008). Language minority students and California community colleges: Current issues and future directions. Community College Policy Research, 1. Retrieved 7/10/2014, from http://c4.ucr.edu/images/pdf/C4PolicyResearchJournalIssue1Spring2008.pdf

Chang, Y. (2011). Picking one's battles: NNES doctoral students' imagined communities and selections of investment. Journal of Language, Identity, and Education, 10(4), 213-230.Chang, Y. (2010). Discourse and identity in online language learning: A case study of a community college ESL classroom (Doctoral dissertation). Retrieved from ProQuest/UMI Dissertation Publishing.

Chang, Y. \& Sperling, M. (2014). Discourse and identity among ESL learners: A case study of a community college ESL classroom. Research in the Teaching of English, 49(1), 31-51.

Cheng, A. (2008). Analyzing genre exemplars in preparation for writing: The case of an L2 graduate student in the ESP genre-based instructional framework of academic literacy. Applied Linguistics, 29(1), 50-71.

Chisman, F. P., \& Crandall, J. (2007). Passing the torch: Strategies for innovation in community college ESL. New York, NY: Council for the Advancement of Adult Literacy.

Cohen, A. \& Brawer, F. (2008). The American community college. (5th ed.) San Francisco, CA: Jossey-Bass.

Condelli, L. (2004). Effective instruction for adult ESL literacy student: Findings from the what works study. Washington, DC: American Institute for Research.

Crandall, J., \& Sheppard, K. (2004). Adult ESL and the community college. New York, NY: Council for the Advancement of Adult Literacy.

Crystal, D. (2012). English as a global language (2 ${ }^{\text {nd }}$ ed.). New York, NY: Cambridge University Press.

Curry, M. J. (2004). UCLA community college review: Academic literacy for English language learners. Community College Review, 32(2), 51-68.

Darvin, R. \& Norton, B. (2015). Identity and a model of investment in applied linguistics. Annual Review of Applied Linguistics, 35, 36-56.

Flowerdew, J. \& Miller, L. (2008). Social structure and individual agency in second language learning: Evidence from three life histories. Critical Inquiry in Language Studies, 5(4), 201-224.

Gee. J. P. (1996). Social linguistics and literacies: Ideology in discourses. New York, NY: Routledge.

Gee, J. P. (2000-2001). Identity as an analytic lens for research in education. Review of Research in Education, 25, 99 125.

Gee, J. P. (2001). Literacy, discourse, and linguistics: Introduction and what is literacy? In E. Cushman, E. R. Kintgen, B. M. Kroll \& M. Rose (Eds.), Literacy: A critical sourcebook (pp. 525-44). New York: Bedford/St. Martin's. (Reprinted from Journal of Education, 1989, 171(1), pp. 5-25.)

Glaser, B., \& Strauss, A. (1976). The discovery of grounded theory. Chicago: Aldine.

Gordon, D. (2012). "I'm tired. You clean and cook." Shifting gender identities and second language socialization. TESOL Quarterly, 38(3), 437-457.

Graddol, D. (1998). The future of English. London, UK: The British Council.

Haneda, H. (2005). Investing in foreign-language writing: A study of two multicultural learners. Journal of Language, Identity \& Education, 4(4), 269-290.

Harklau, L. (2000). From the "good kids" to the "worst": Representations of English language learners across educational settings. TESOL Quarterly, 34(1), 35-67.

Higgins, C. (2011). "You're a real Swahili!”: Western women's resistance to identity slippage in Tanzania. In C. Higgins (Ed.). Identity formation in globalizing contexts: Language learning in the new millennium (pp. 127-145). Boston, MA: De Gruyter Mouton.

Hood, M. (2009). Case study. In J. Heigham \& R. A. Croker (Eds.). Qualitative research in applied linguistics: A practical introduction (pp. 66-90). New York, NY: Palgrave Macmillan.

Hyland, K. (2007). Genre pedagogy: Language, literacy and L2 writing instruction. Journal of Second Language Writing, $16(3), 148-164$.

Jackson, J. (2011). Mutuality, engagement, and agency: Negotiating identity on stays abroad. In C. Higgins (Ed.). Identity formation in globalizing contexts: Language learning in the new millennium (pp. 127-145). Boston, MA: De Gruyter Mouton. 
Kanno, Y. \& Norton, B. (2003). Imagined communities and educational possibilities: Introduction. Journal of Language, Identity, \& Education, 2(4), 1 241-249.

Kanno, Y. \& Varghese (2010). Immigrant and refugee ESL students' challenges to accessing four-year college education: From language policy to educational policy. Journal of Language, Identity, \& Education, 9(5), 310-328.

Kramsch, C. (1993). Context and culture in language teaching. Oxford: Oxford University Press.

Kuo, E. W. (1999). English as a second language in the community college curriculum. New Directions for Community Colleges, 108, 69-80.

Leki, I. (2007). Undergraduates in a second language: Challenges and complexities of academic literacy development. Mahwah, NJ: Lawrence Erlbaum.

Levin, J. (2007). Nontraditionall students and community colleges: The conflict of justice and neoliberalism. New York, NY: Palgrave Macmillan.

Liu, P. \& Tannacito, D. (2013). Resistance by L2 writers: The role of racial and language ideology in imagined community and identity investment. Journal of Second Language Writing, 22, 355-373.

Matsuda, P. K. (2006). The myth of linguistic homogeneity in U.S. college composition. College English, 68(6), 637651.

Matsuda, P. K., Ortmeier-Hooper, C. \& You, X. (Eds.). (2006). The politics of second language writing: In search of the promised land. West Lafayette, IN: Parlor Press.

McKay, S. L. \& Wong. S. C. (1996). Multiple discourses, multiple identities: investment and agency in second-language learning among Chinese adolescent immigrant students. Harvard Educational Reviews, 66(3), 577-608.

Merriam, S. B. (1998). Qualitative research and case study applications in education: Revised and expanded from case study research in education. San Francisco, CA: Jossey-Bass Publishers.

Miele, C. (2003). Bergen Community College meets Generation 1.5. Community College Journal of Research and Practice, 27, 603-612.

Morita, N. (2009). Language, culture, gender, and academic socialization. Language and Education, 23(5). $443-460$.

Norton, B. (2000). Identity and language learning: Gender, ethnicity and educational change. Harlow, England; New York: Longman.

Norton, B. (2014). Identity, literacy, and the multilingual classroom. In. S. May (Ed.) The multilingual turn: Implications for SLA, TESOL and Bilingual Education. NY: Routledge.

Norton, B. \& Toohey, K. (2011). Identity, language learning, and social change. Language Teaching, 44, 412-446.

Pavlenko, A. (2002). Poststructuralist approaches to the study of social factors in second language learning and use. in V. Cook. (Ed.), Portraits of the L2 User (pp. 277-301). Buffalo, NY: Library of Congress Cataloging in Publication Data.

Razfar, A. \& Simon, J. (2011). Course-taking patterns of Latino ESL students: Mobility and mainstreaming in urban community colleges in the United States. TESOL Quarterly, 45(4), 595-627.

Roberge, M., Siegal, M., \& Harklau, L. (Eds.). (2009). Generation 1.5 in college composition: Teaching academic writing to U.S.-educated learners of ESL. New York, NY: Routledge.

Vann, R., Richardson, B., \& Escudero, M. (2006). Negotiating identities in a multilingual science class. In T. Omoniyi \& G. White (Eds.). The sociolinguistics of identity (pp. 201-216). New York, NY: Continuum.

Wang, H. (Ed.). (2012). Globalizing China: The influence, strategies and successes of Chinese Returnees. Bingley, UK: Emerald Group Publishing.

Zamel, V. (1995). Strangers in academia: The experiences of faculty and ESL students across the curriculum. College Composition and Communication, 46(3), 506-521. 
Notes:

i Some community college ESL courses are offered for college credit (although they typically are not transferrable to a four-year university); other classes do not carry college credit. Non-credit ESL courses usually focus on survival language skills with the aim of helping immigrants improve their functional literacy in the United States. Credit ESL courses aims to provide students with the academic language necessary to succeed in college classes.

ii All names are pseudonyms.

\section{Appendix A}

Interview Protocol--Focal Students

- $\quad$ Tell me about you.

- What is your name?

- How old are you?

- What country are you from?

○ How long have you been in the U.S.? What is your visa status?

- What is your educational level before you came to the U.S.?

- What does your life in the U.S. look like?

- Who are the people you frequently get in contact with during your stay at the U.S.?

○ What do you plan to do after you finish study here?

- Tell me about your life at the college.

○ How long have you attended College X?

- How do you like your life here at College X?

$\circ$ What is your goal here?

- In addition to ESL courses, are you enrolled in any academic department? What are the courses you are taking this semester?

- How do you think the education at College X will help you achieve your life goals?

- $\quad$ Tell me about your previous English language learning experiences.

- What do you need English for?

○ When did you start to learn English? Have you been learning English since then?

- What schools have you attended before teach you English?

- In addition to the ESL on campus, have you enrolled in other ESL class?

- Is your English learning experiences at other schools similar to or different from that at College X?

- Tell me how you feel about the ESL class you are taking.

○ Why did you enroll into this class?

- What do you think you are learning from this course?

○ What do you like best/least about this class?

- Is your English language learning experience at the class similar to or different from other ESL courses you have attended before? In what ways are they similar/different?

○ Do you consider yourself an active participant in the class? 


\section{Appendix B}

Interview Protocols--Instructors

- Tell me something about yourself, such as where you are from, your educational experiences, and your teaching experience.

- Tell me more about the class.

- What is the curriculum structure of this course?

- What goals or outcomes do you expect to accomplish in this level of course?

○ How is the curriculum of this course (e.g. textbook, the topic of horse racing) decided?

- $\quad$ Tell me something about your students at class X.

- I noticed there are a lot of Asian students in the class, particularly students from China. Why do Asian students predominate the class demographics?

- How are the students identified as an ESL learner and placed into this class?

- How do they move from one ESL course to another?

- How is their achievement assessed in this course?

- What are their educational pathways within the college? How do they go from ESL to academic or vocational programs?

- I also noticed many students have to work after the class, is it common for ESL students to keep a job in addition to maintain a full-time student status? Does their work affect their performance at the class?

- Identifying focal students in terms of their academic and social ability

- Have you noticed any students whose academic abilities are above average of the class? Have you noticed anyone falling behind in terms of meeting your expectation on course works, and the ability to write academic essays?

- Have you noticed any students who are more active in the classroom or can better meet your social expectation? Anyone who is quieter or not as active as the others?

- Could you briefly comment on each of the following students (names of focal students)?

○ How do you perceive his/her academic abilities?

- Is he/she an active participant at class?

○ Have you noticed any improvement in their language proficiency since he/she enrolled in this class? 